\title{
Brazil: capital goods industry during the 2003-2008 boom and following the global crisis
}

\author{
Guilherme Riccioppo Magacho
}

ABSTRACT

The capital goods industry is essential for technological development and long-term economic growth without external restrictions. After a long period of stagnation, investment growth resumed in Brazil in 2003 and brought renewed vigor to the capital goods industry. Nevertheless, the industry is very diverse, and some sectors have failed to meet rising demand where others have succeeded, namely those with high technological potential such as suppliers of machinery for the oil, mining and construction industries and makers of transportation and electrical generation and distribution equipment. Those sectors continued to expand even in the wake of the 2008 global crisis and have been barely touched by foreign competition. 


\section{I}

\section{Introduction}

The capital goods industry manufactures the machinery needed to produce other goods, which makes it essential for economic development. This industry plays an important role in disseminating technological progress - while also bringing technology users closer to producersand is vitally important to the technological progress of an economy (Lundvall, 1988). In addition, it reduces external vulnerability inasmuch as economic growth, in the absence of relevant parts of the capital goods sector, becomes more dependent on the net exports of other sectors of the economy, or on foreign capital flows to provide the foreign currency needed to increase investment. ${ }^{1}$

From these two perspectives, evaluating the capital goods sector is an important step in assessing economic growth prospects in the years ahead, whether under favourable external conditions, such as between 2003 and 2008 , or under conditions less conducive to productive expansion, such as prevailed in the wake of the 2008 global financial crisis.

Following a first disruption to the supply structure in the 1980s (when micro-electronics were introduced in manufacturing processes and products) and a second one in the 1990s (trade liberalization and low growth

1 This paper is based on the author's master's thesis, defended at the Institute of Economics/State University at Campinas (UNICAMP). The author wishes to thank professor Mariano Laplane, who was his advisor, and professors Rogério Gomes and Célio Hiratuka for their contributions to the examination and defense of his thesis. He also appreciates the suggestions and comments made by an anonymous reviewer of this journal. rates), the machinery and equipment manufacturing industry experienced a third disruption with the cycle of economic expansion that began in 2003. The ensuing boom years have appeared to reverse the stagnation trend that had lasted for at least two decades, ushering in a considerable increase in investment and, by extension, in demand for capital goods.

In order to facilitate sector expansion in the event that the economic growth continues, the sector and its component industries have been analysed in terms of capacity to meet domestic demand and production and competitiveness structure. The proposal is to consolidate the necessary data on the structure of the various segments of the capital goods industry, to support an analysis of its repercussions on the country's economic growth and technological development.

This paper has five sections, including this Introduction. The second section gives a brief description of the recent cycle of expansion, noting its origins and immediate consequences for the Brazilian economy and, in particular, its repercussions on sector investments. The third section presents the methodology used to evaluate the industry and the way in which it has been segmented. The fourth section gives a brief overview of current conditions in the capital goods industry and analyses its main segments, noting their discrepancies with respect to sector demand. Lastly, in conclusion, the main findings of the analysis are presented with a view to developing an effective industrial policy for the capital goods sector.

\section{II}

\section{The 2003-2008 boom cycle and the new postcrisis dynamic}

In Brazil, the 1980s and 1990s were characterized first and foremost by a flat economy. Weak growth was accompanied by high unemployment and low fixed capital investment. Although there were some expansionary cycles, such as in 1995-1997 (a period referred to by Bielschowsky (1999) as the "modernization mini-cycle"), the overall trend during those two decades was one of weakening economic activity, rising numbers of unemployed workers and falling levels of global investment in the economy.

That period of stagnation came to an end in 2004, when Brazil's economy resumed a sustained economic 
growth path: average annual growth rates rose from $2.1 \%$ in $1999-2002$ to $3.5 \%$ in $2003-2006$ and $4.5 \%$ in 2007-2010. However, the economy lost steam when the 2008 crisis hit, and in the three years from 2011 to 2013 the growth rate fell to 1999-2002 levels (annual average rate of $2.1 \%$ ) (see figure 1 ).

FIGURE 1

Brazil: annual rate of economic growth, 1990-2013

(Annual variation, in percentages)

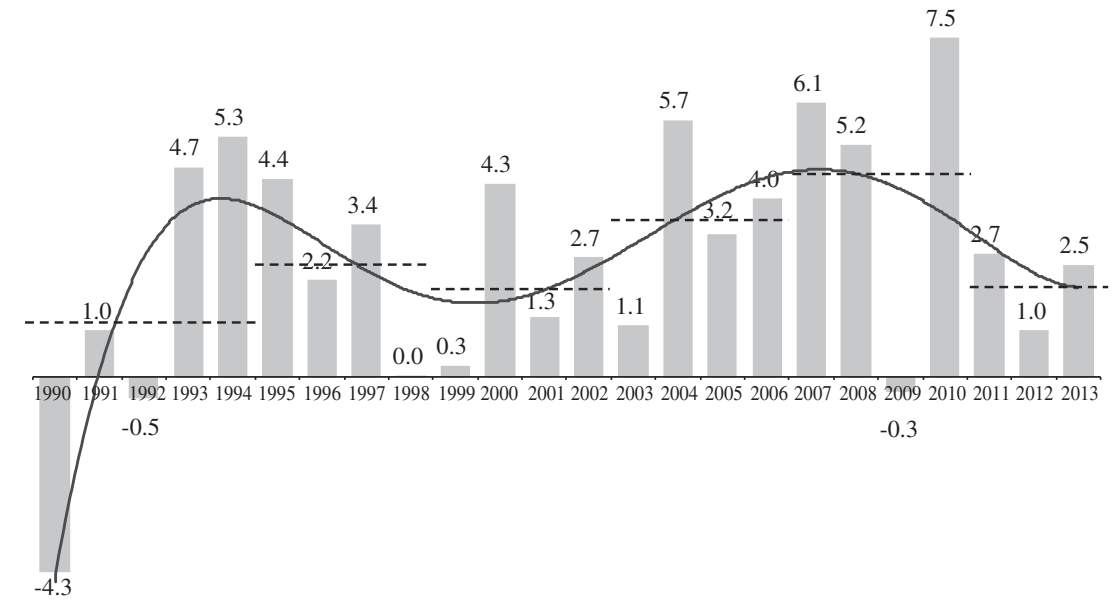

Source: Prepared by the author, on the basis of the National Accounts System of the Brazilian Geographical and Statistical Institute (IBGE).

\section{Overview of the 2003-2008 expansionary cycle and post-crisis stagnation}

The resumption of growth and the rapid expansion of international trade that followed the recovery of liquidity levels and rising demand in China changed some aspects that had hitherto characterized the global economy. Dollar-denominated commodity prices began to recover in 2003, reversing the downward trend of the previous years, and capital flows were redirected towards emerging countries, which saw considerable improvements in their balance of payments as interest rate spreads on their sovereign debt narrowed and trade flows reversed (Serrano and Summa, 2011).

Better external conditions for the emerging countries (especially net commodity exporters) propelled a course change in those economies, which began to grow at a faster clip than in previous years. Brazil was no exception. Once the crisis associated with the change in government had ended, the national economy began to benefit from the improved external environment.

As illustrated in figure 2, installed capacity utilization began to increase in 2004, rising from $80.3 \%$ in 2003 to $83.3 \%$ in 2006 . This translated into an increase in the investment rate, especially in the machinery and equipment sector, which grew from $7.2 \%$ to $8.5 \%$ of gross domestic product (GDP) over the same period. The trend strengthened in 2007 and 2008, when installed capacity utilization surpassed $85 \%$ and demand appeared to be sustainable, driving the rate of investment - the main component of which became machinery and equipment - to $19.1 \%$.

However, a sharp deterioration in the utilization rate beginning in 2010, owing to uncertainty about external and domestic demand, precipitated a decline in the rate of investment in machinery and equipment, from $10.2 \%$ to $9.0 \%$ in 2012 , followed by an increase to $9.5 \%$ in 2013 .

This new environment represented a significant departure from the boom cycle of 2003-2008. Starting in 2008, the emerging economies began to experience much lower growth rates, and the developed economies recorded negative or virtually zero growth. ${ }^{2}$ This had major repercussions for the Brazilian economy. Despite the countercyclical measures adopted in response to the crisis, growth sank and demand for imported products rose owing to the real appreciation in the Brazilian currency starting in 2011 and an oversupply of manufactured goods in a context of flagging global demand.

\footnotetext{
${ }^{2}$ According to the World Bank (World Development Indicators), the advanced economies grew at an average annual rate of $2.5 \%$ in the period $2003-2008$ but just $0.8 \%$ in the period 2008-2013, whereas the annual growth rate in emerging countries slipped from $7.4 \%$ to $5.3 \%$ over the same period.
} 


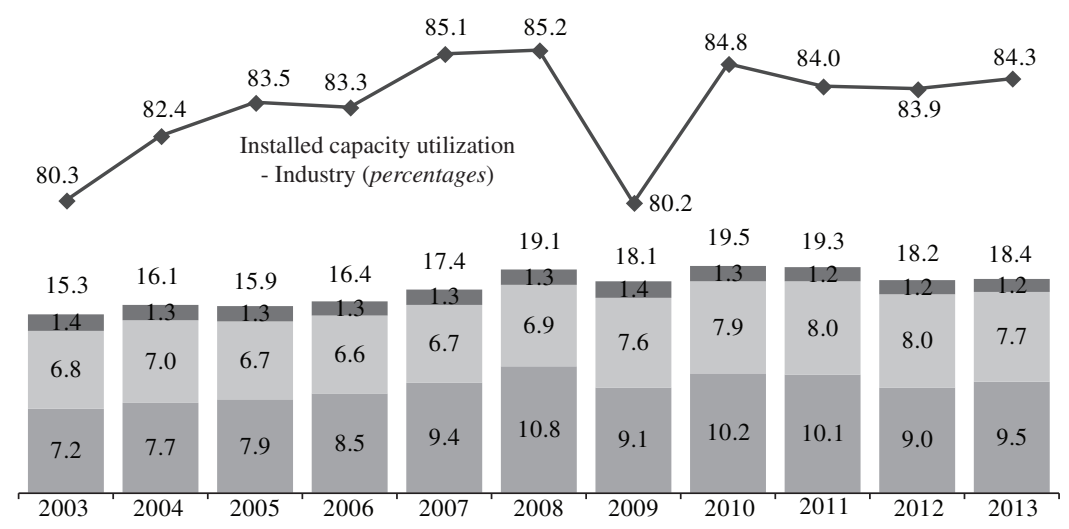

Gross fixed capital formation - others (percentage of GDP)

Gross fixed capital formation - construction (percentage of GDP)

Gross fixed capital formation - machinery and equipment (percentage of GDP)

$\sim$-Installed capacity utilization - industry (percentages)

Source: Prepared by the author, on the basis of data from the National Accounts System of the Brazilian Geographical and Statistical Institute (IBGE) and the Getulio Vargas Foundation.

Note: GDP: Gross domestic product.

\section{Effects of the growth cycle on sector investments}

Despite the fact that the increases in production, and especially in investment, in the period 2003-2008 were seen industry-wide, the gains did not extend to all sectors. Some groups of industrial activities drove the increase in business investment in that period, either through export activity (as previously seen) or because they were largely unaffected by the penetration of imported products. ${ }^{3}$ Analogously, the economic slowdown that began in 2008 also had varying effects on the different sectors and their investments.

Some sectors stand out as the main drivers of rising investment activity during the period. As illustrated in table 1, the oil and gas, agro-industry, metallurgy, mining and paper and pulp sectors were the main beneficiaries of the growth cycle and saw larger increases in investment, especially comparing 2006-2008 against 2003-2005.

\footnotetext{
3 The penetration of imported products was explained, above all, by exchange rate appreciation and, in parallel, by more imports of products from Asian countries (especially China).
}

The oil and gas, agro-industry, metallurgy, mining and paper and pulp sectors, which together accounted for less than half of total investment in the 2000-2002 period, came to represent $66.6 \%$ of the total in 20062008. The investments of this group of sectors rose from $\mathrm{R} \$ 111.1$ billion to $\mathrm{R} \$ 246.9$ billion between the first and last quarters under analysis (in 2009 values), or a $122.3 \%$ increase (i.e. $14.2 \%$ per year).

However, the sector distribution of investments changed significantly following the 2008 crisis. While in some sectors, such as oil and gas, agro-industry and mining, investments continued to trend upwards (total investment grew from R\$ 161.1 billion in 2006-2008 to $\mathrm{R} \$ 249.6$ billion in 2010-2012), in others, such as metallurgy and paper and pulp, investments fell dramatically (total investments for these two sectors decreased from $\mathrm{R} \$ 65.8$ billion to $\mathrm{R} \$ 46.4$ billion over the same period). As a result, the post-crisis period was characterized by an even greater concentration of investments, with $56 \%$ of industry investment going to just three sectors: oil and gas, agro-industry and mining. 


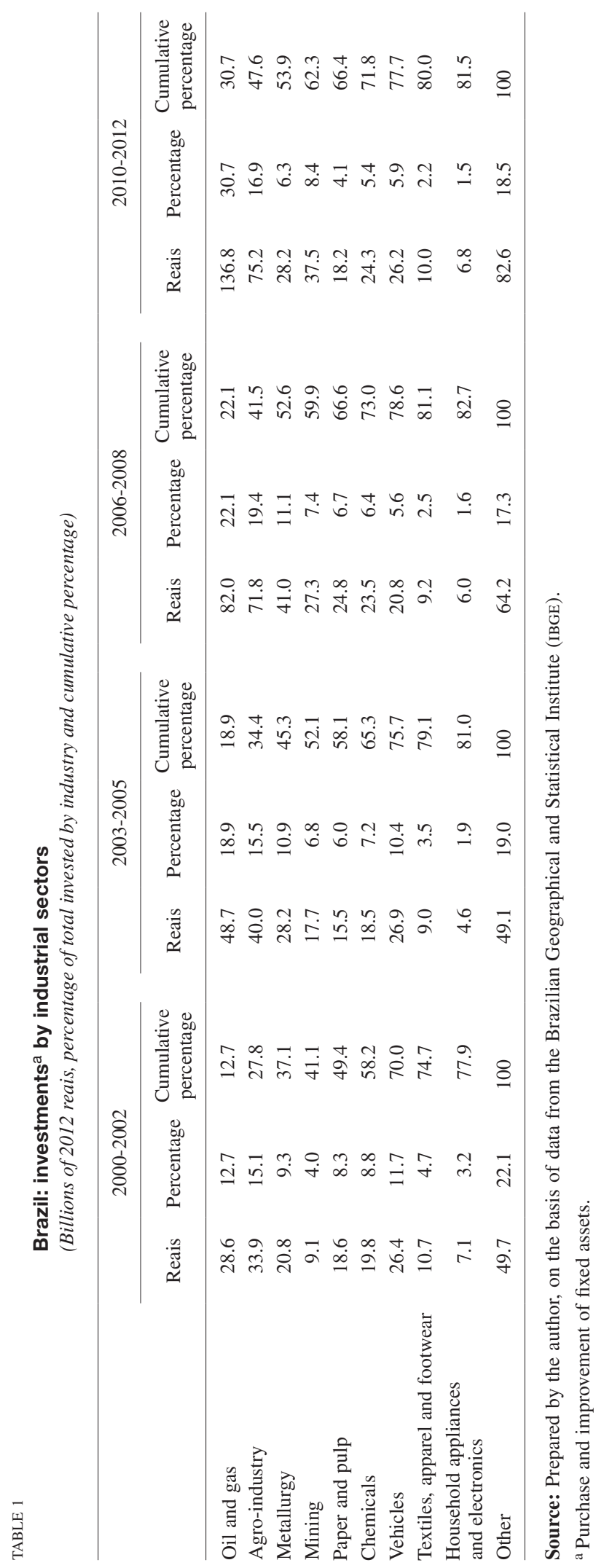




\section{III}

\section{Analysis of the capital goods industry: methodological aspects}

The capital goods industry is easily defined by the function of the products it makes: capital goods are used to produce other goods and, unlike inputs, are used repeatedly and are not transformed in the production process.

Defining capital goods is simple, but selecting a typology to analyse the capital goods manufacturing sector is not, nor can it be comprehensive. Because the sector is not composed of a specific industry but rather a number of industries that link up based on the end use of the manufactured goods, the results of a sector analysis depend above all on the typology used to distinguish it, which must fit the purpose of the study.

\section{Classification of the capital goods industry}

The capital goods industry has traditionally been classified based on a characteristic of the process by which the goods are manufactured: they can be mass-produced or made to order. The mass production of capital goods is standardized, subject to important static economies of scale and tends, in most cases, to require minimum production scales that are quite high. Capital goods that are made to order are produced according to the specifications of the industry that will use them, in most cases in association with the maker of the goods. Robust economies of scale, derived from extensive experience with planning and making similar goods, are important in order for this industry to perform well (Nassif, 2008; Vermulm and Erber, 2002).

However, this type of segmentation is unsuited to the purposes of this study. Inasmuch as the objective is to analyse the performance of the capital goods industry in the face of changes in the structure of demand, the traditional classification is discarded in favour of a demand-based classification. This alternative typology seeks to capture the segmentation of this industry based on the investor sector, with special attention paid to the reliance of these sectors on the domestic production of capital goods for the expansion, generation and absorption of technology.

In this paper, the capital goods industry is divided into five large groups based on the National Classification of Economic Activities (CNAE) of the Brazilian Geographical and Statistical Institute (IBGE). ${ }^{4}$ Subsequently, an analysis will be carried out, within the industrial machinery and equipment segment, to identify the potential differences that may exist in the supply of capital goods based on the demand sectors.

\section{Structure, source of data and indicators used for the analysis}

For purposes of analysing the capital goods industry, its main segments and the sectors of the industrial machinery and equipment segment, this study examines the evolution of national production and domestic demand. In the first case, the key aspect is the source of demand (domestic or external market), and in the second case, it is the origin of the product (local or imported). To look at these aspects, data on industrial transformation value and gross value of industrial output was gathered from the IBGE Annual Survey of Industry-Enterprise (research unit: local unit) for the five segments, and also on the value of output from the IBGE Annual Survey of Industry-Product, for sectors in the industrial machinery and equipment segment.

Import and export data, expressed in kilograms and dollars, was taken from AliceWeb, a trade data analysis system run by the Ministry of Industry, Foreign Trade and Services (MDIC). Based on the data, calculations were made of apparent consumption (production plus imports minus exports), the export ratio (ratio of exports to production) and the import penetration ratio (ratio of imports to apparent consumption).

In the case of sectors with relatively high levels of imports and exports, the Grubel-Lloyd index ${ }^{5}$ is evaluated to measure the extent to which trade is interor intra-industrial. ${ }^{6}$ Based on this evaluation, it can be

\footnotetext{
${ }^{4}$ See annex A1 for the list of sectors comprising the groups.

5 Calculated for the eight-digit level of the MERCosur Common Nomenclature (MCN).

6 The Grubel-Lloyd index is calculated as the ratio of the sum of the difference between exports and imports of each product in the numerator to the sum of exports and imports in the denominator. Values closer to the unit indicate the predominance of intra-industry trade, and conversely, values closer to zero indicate the predominance of inter-industry trade.
} 
determined whether the national industry would or would not be able to replace the capital goods that have been imported. The ratio between the export unit value and the import unit value, measured in dollars per kilogram, suggests the size of the technological gap between the local products and imports, to establish whether trade is horizontal or vertical. ${ }^{7}$

These data are used to assess the current and potential capacity of each segment of Brazil's industrial sector to supply the capital goods required by the national manufacturing sector. The focus on the indicators has

${ }^{7}$ According to Resende y Anderson (1999), Feltrin (2005) and Baltar (2007), the literature in economics considers intra-industry trade to be horizontal when the ratio between the export unit value and the import unit value falls between 0.85 and 1.15 , and vertical otherwise. to do with the suspicion that a large portion of the goods imported for national investment are not very different, in terms of technological level, from goods produced in the country.

With this in mind, the proposal is to analyse whether local industry would, in fact, be unable to meet domestic demand due to lack of technological development, or whether it is instead the case that robust growth in investment following decades of stagnation is generating demand that the national capital goods industry does not have enough installed capacity to meet, causing a mismatch between domestic supply and demand for these goods and driving imports. The main objective is to identify the segments where this is frequently the case and where the national capital goods industry would not be able to supply other national industries, including from a technological point of view.

\section{IV}

\section{Overview of the capital goods industry in Brazil}

The size of Brazil's capital goods industry is reflected in the GDP of the industrial sector, which was R $\$ 88.3$ billion in 2012. No less important is its capacity to create jobs. According to the IBGE Annual Survey of IndustryEnterprise, as of 31 December 2012, makers of capital goods directly employed over 690,000 workers, or $10.7 \%$ of the manufacturing workforce. Against this backdrop, the factors that have driven capital goods production and trade relations must be understood as part of an analysis of the sector.

\section{General characteristics of the capital goods industry}

With demand on the rise between 2003 and 2008 (and especially after 2006), the output of the capital goods industry outpaced GDP. Sector GDP, measured using the industrial transformation value, grew at a real annual rate of $8.8 \%$, while national GDP growth, although high, was nevertheless lower than 5\%. Albeit at a slower pace, the capital goods sector continued to expand despite the slowdown in GDP growth after 2008. In terms of production, for example, annual growth cooled to 5.5\% between 2008 and 2012, a relative slowdown, as illustrated in figure 3.

The increase in production of capital goods in the period 2003-2012 was characterized by three distinct cycles. In the first, between 2003 and 2004, there was a sudden jump in external demand for investment goods, such that the sector — which had low production capacity after many years of scarce investment in the Brazilian economy - came to use nearly its full installed capacity. In the second, between 2006 and 2008, the intensity and duration of domestic demand for machinery and equipment grew, providing assurance of the continued use of production capacity, which translated into investments aimed at increasing the sector's supply capacity. Lastly, in the third cycle, between 2008 and 2012, the economic slowdown and weaker investment precipitated a decline in the growth rate of the capital goods sector, which continued to grow despite the loss of momentum.

As illustrated in figure 4, while national investment (measured as apparent consumption of machinery and equipment) posted slight increases from mid-2003 to 2004, installed capacity utilization in the sector peaked $(85.6 \%)$ in October 2004, mainly owing to rising external demand for machinery and equipment, from $\mathrm{R} \$ 30.6$ billion in 2003 to $\mathrm{R} \$ 51$ billion in 2005 . $^{8}$

\footnotetext{
${ }^{8}$ Exports of capital goods grew from $\mathrm{R} \$ 20.6$ billion to $\mathrm{R} \$ 51$ billion between 2000 and 2004 (annual growth of $25.4 \%$ ), and the sector's export ratio increased from $32.5 \%$ to $40.0 \%$, well above its historic average.
} 
FIGURE 3

Brazil: output and employment in the capital goods industry, 2000-2012 (Billions of 2012 reais $^{\mathrm{a}}$ and thousands, respectively)

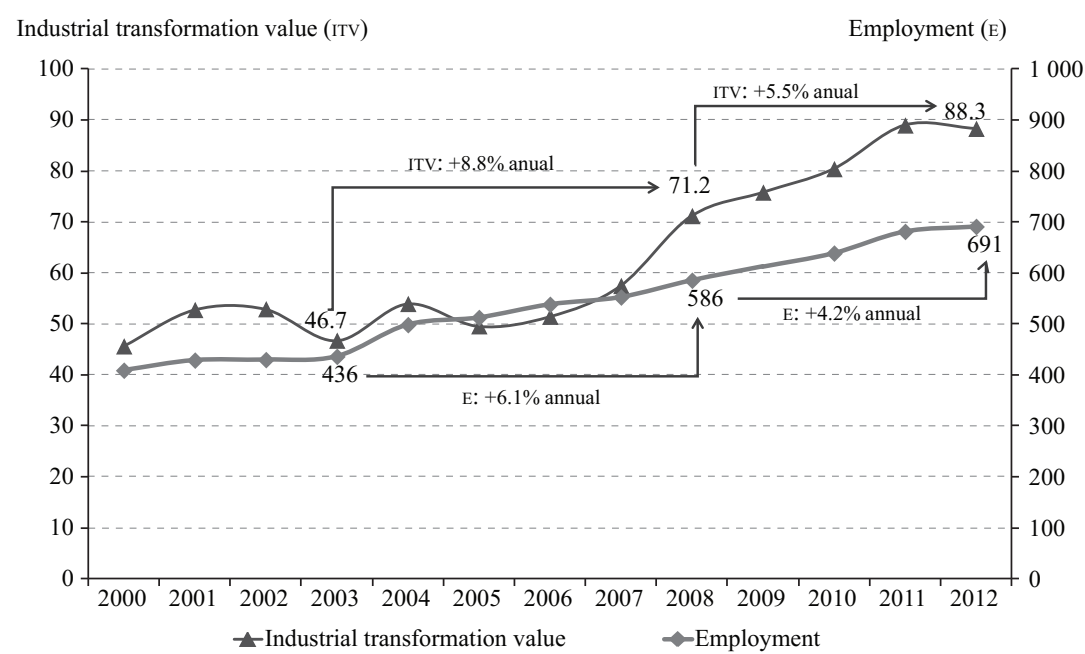

Source: Prepared by the author, on the basis of data from the Brazilian Geographical and Statistical Institute (IBGE) and the Getulio Vargas Foundation.

a Deflated using the Getulio Vargas Foundation's wholesale price index-global supply corresponding to the sector. Data from 2009 were excluded to facilitate the visualization.

FIGURE 4

Brazil: apparent consumption and installed capacity utilization in the machinery and equipment sector, 2003-2011

(Percentages and index number: average $1996=100$, respectively)

Installed capacity utilization (ICU)

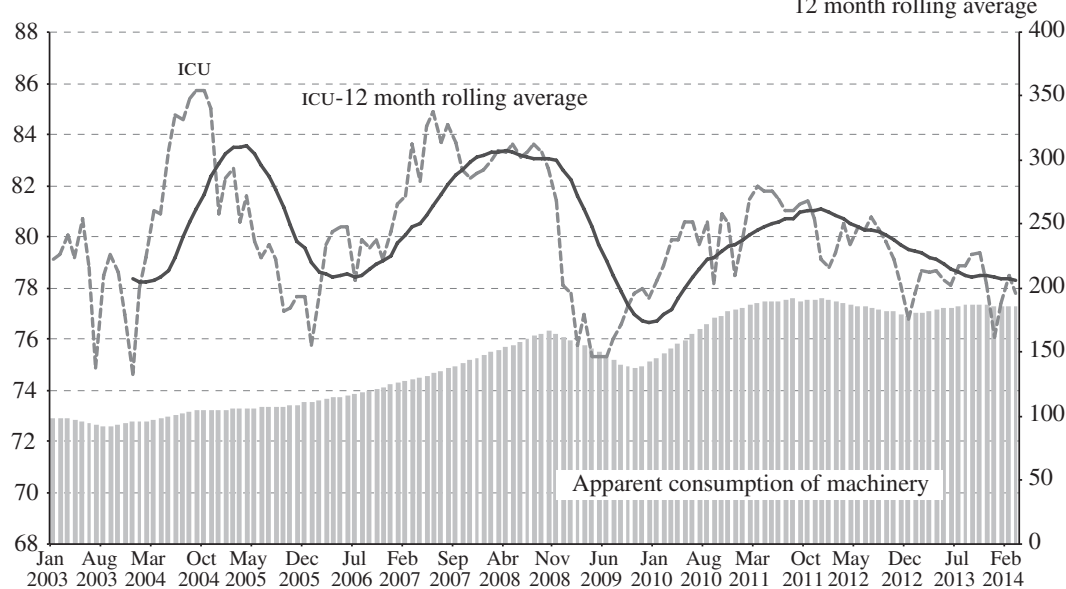

Apparent consumption of machinery 12 month rolling average

Source: Prepared by the author, on the basis of data from the Institute of Applied Economic Research (IPEA) and the National Confederation of Industry (CNI).

However, there was a fairly dramatic shift in the following period. Starting in 2006, investment in machinery and equipment in the country climbed sharply, driving up the rate of installed capacity utilization in the capital goods industry, which remained high for successive years
(84.6\% in August 2007 and 84.1\% in July 2008, and above $82 \%$ between January 2007 and October 2008).

Following the decline in activity in 2009, investment rebounded but at a weaker pace than in the earlier period of robust growth. By the end of 2011, investment had 
stalled, and the capacity utilization rate in the sector, which had not returned to the pre-crisis level (remaining below $82 \%$ ), began to fall.

The increase in demand for capital goods between 2006 and 2008, propelled mainly by higher industrial and public investment, ${ }^{9}$ had a major impact on Brazil's trade in capital goods. National production of these goods - which during the period of weak investment was subject to an exportoriented restructuring process- was reoriented to the domestic market, particularly after 2005, when national investment rose and the exchange rate began to appreciate (making exports less competitive).

Inasmuch as less use was made of installed capacity and demand for investment goods rose, the 2003-2008 period of economic growth in Brazil had major repercussions for production and sales of capital goods in the country. After several decades of stagnation, the demand shock prompted makers of machinery and equipment to rapidly bring nearly all of their production capacity on line and resume the capacity to use, make and buy inputs to sustain the growth cycle.

${ }^{9}$ According to data from the Institute of Applied Economic Research (IPEA), public investment (including state investment) rose from $2.7 \%$ to $3.7 \%$ of GDP between 2005 and 2008 .
In 2008, the capital goods industry entered a new phase as domestic demand for machinery and equipment waned on falling growth and flat investment in the country. Exports, which had become less competitive in the 2006-2008 cycle, weakened further, as the slowdown in the global economy and the appreciation in the exchange rate impeded access to foreign markets. Imports, meanwhile, continued to grow, curtailing sector growth and causing further deterioration to the trade balance.

\section{Main segments of the capital goods industry}

As mentioned previously, the production of capital goods, measured as the industrial transformation value, totaled $\mathrm{R} \$ 88.275$ billion in 2012. The industrial machinery and equipment and the transportation equipment segments stood out, with production totaling $\mathrm{R} \$ 34.126$ billion and $\mathrm{R} \$ 24.665$ billion, respectively, followed by the computer, electronics and optical equipment segment, with production valued at $\mathrm{R} \$ 13.554$ billion in 2012. Lastly, the production totals for the electrical equipment and farm machinery and equipment segments were lower but still significant at $R \$ 8.379$ billion and $R \$ 7.551$ billion, respectively (see figure 5).

FIGURE 5

Brazil: industrial transformation value (ITV) by segment, 2000-2012 (Billions of 2012 reais $^{\mathrm{a}}$ )

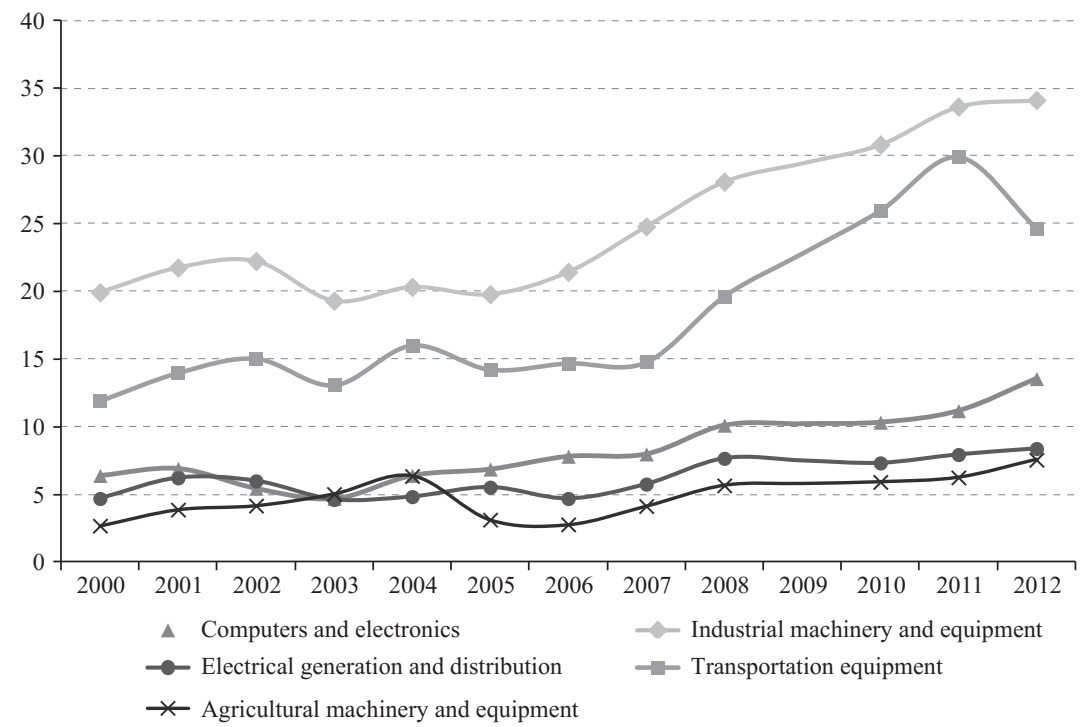

Source: Prepared by the author, on the basis of data from the Brazilian Geographical and Statistical Institute (IBGE) and the Getulio Vargas Foundation.

a Deflated using the Getulio Vargas Foundation's wholesale price index-global supply corresponding to the sector. Data from 2009 were excluded to facilitate the visualization. 
Although production rose in all segments between 2003 and 2012, the growth process and phases differed significantly from one segment to another. As mentioned, external demand was the driving force in the first cycle of growth. Not coincidentally, the segments that were more export-oriented (computer, electronics and optical equipment, farm machinery and equipment and transportation equipment) posted the strongest growth in 2004 (and also continued to grow in the subsequent cycle). ${ }^{10}$

Growth in the second cycle (2006-2008) was more propelled by expansion in the domestic market, especially in industrial investment. Indeed, growth in the industrial machinery and equipment and electrical equipment segments, both heavily reliant on domestic demand, was concentrated in the second half of the 2000s.

10 The exception is the computer, electronics and optical equipment segment, which relied heavily on the domestic market, but as a supplier for export sectors nevertheless posted virtually uninterrupted growth from 2003-2012.
Starting in 2008, the export-oriented segments of the capital goods industry found it harder to expand because in addition to the appreciation in the exchange rate that had curbed growth in the previous cycle, demand among trade partners fell. Thus, expansion in the postcrisis period was driven by the local market, albeit at a much slower pace.

As illustrated in figure 6, which disaggregates the increase in total production (measured as the gross value of industrial output) by exports and domestic demand, growth in the capital goods sector between 2002 and 2004 was largely driven by external demand. In the transportation equipment and farm machinery and equipment segments, which had nominal growth rates of $81 \%$ and $114 \%$, respectively, during this period, over half of the growth was directly attributable to external demand. This was also the case in the industrial machinery and equipment sector, which nevertheless had stronger growth in the second and third cycles, when demand for investment goods was primarily driven by domestic demand.

FIGURE 6 Brazil: changes in production, disaggregated by exports and domestic market,
2002-2012
(Billions of reais)

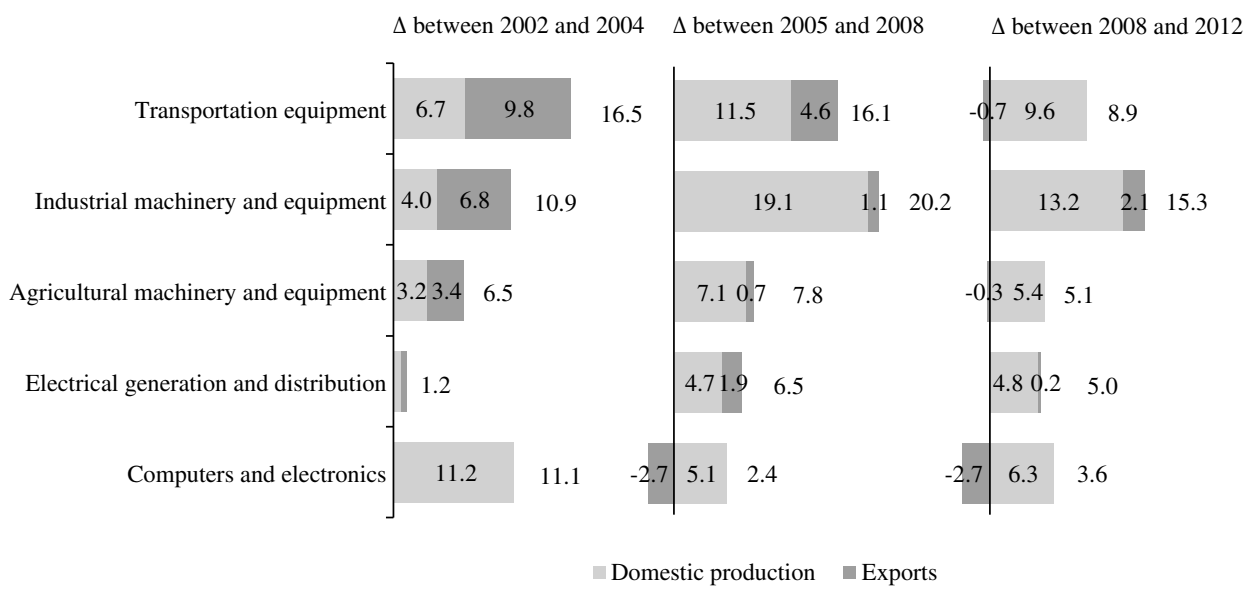

Source: Prepared by the author, on the basis of data from AliceWeb of the Ministry of Industry, Foreign Trade and Services.

In addition to the impact on production analysed earlier, higher investment levels, especially after 2006, had a major impact on imports, strengthened by greater utilization of installed capacity (which acted as an upper limit on further increases in national production) and by appreciation in the exchange rate (which facilitated the penetration of imported products).

As illustrated in figure 7, imports covered much of the increase in domestic demand for capital goods, both in the second cycle of growth (2005-2008) and in 
the subsequent post-crisis cycle (2008-2012). In the industrial machinery and equipment and the computer, electronics and optical equipment segments, imports covered a larger share. In the industrial machinery and equipment sector, owing to the high rate of capacity utilization in Brazilian industry in the second cycle, imports supplemented the national supply in some cases and ended up replacing it in others. In the case of computer, electronics and optical equipment, domestic production was largely replaced by imports, despite idle capacity in the sector. ${ }^{11}$ In this sector of the capital

${ }^{11}$ According to data from the Getulio Vargas Foundation, the rate of utilization of installed capacity in the electrical and communications equipment sectors increased between 2002 and 2005, from $65.4 \%$ to goods industry, which was undoubtedly the hardest hit by imports, lower prices for imported products and the real appreciation in the local currency undermined the domestic and foreign competitiveness of national production, precluding any expansion of this industry in the country. However, inasmuch as this segment mainly produces parts and components for machinery and equipment in other national sectors, replacing domestic supply with cheaper imports could be seen as facilitating growth in other sectors.

$80.3 \%$, and hovered near $80 \%$ in subsequent years. It was only during the 2008 crisis that the rate dropped.

FIGURE 7

\section{Brazil: changes in apparent consumption, disaggregated by imports and domestic production, 2002-2012 \\ (Billions of reais)}

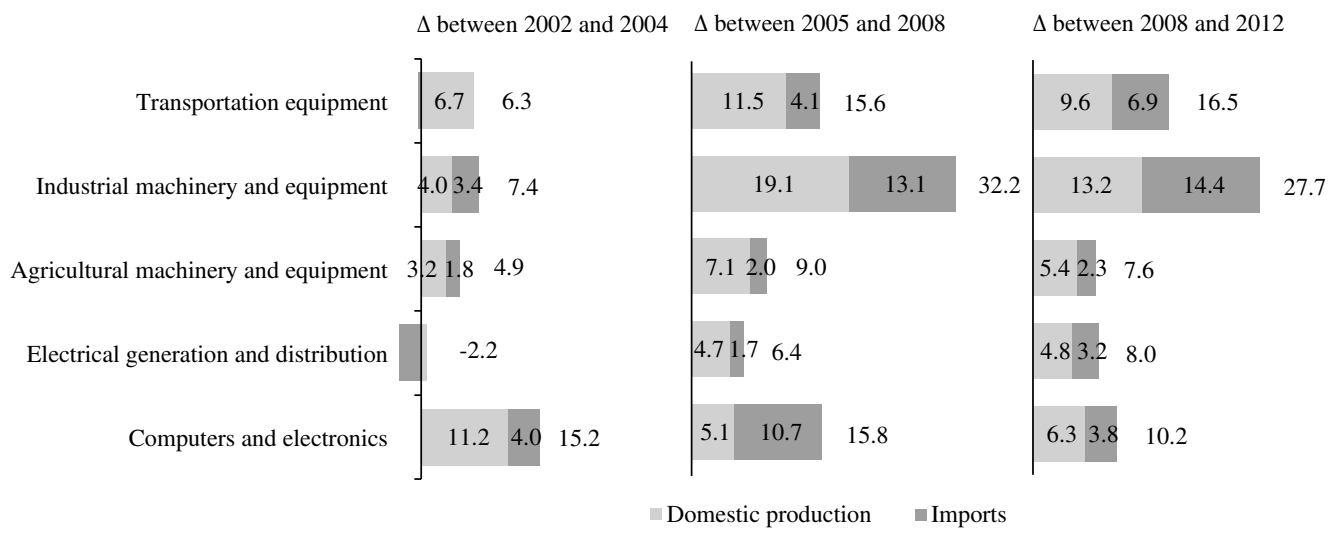

Source: Prepared by the author, on the basis of data from the Brazilian Geographical and Statistical Institute (IBGE) and AliceWeb of the Ministry of Industry, Foreign Trade and Services.

In the three other segments (transportation equipment, electrical generation and distribution equipment and farm machinery and equipment), imports covered a smaller share of the demand for investment goods, despite the fact that nearly all of the nation's industrial production capacity was in use. ${ }^{12}$

\footnotetext{
12 In the sector that makes machinery and equipment for the generation and distribution of electricity, the rate of utilization of installed capacity was $90.3 \%$ in 2007 (the highest level since at least the 1990s), while in the sector that makes transportation equipment, it was $88.5 \%$ in 2005 , where it remained in subsequent years. In the sectors that make equipment for agriculture and rural industries and tractors and machinery for earthmoving, the installed capacity utilization rate rose
}

Analysing the capital goods industry by its main segments leads to the conclusion that it is a very diverse industry, affected variously by demand shocks arising from the recent cycle of growth in the Brazilian economy and by investments made in the post-crisis period of the cycle.

The segments of the industry that manufacture agricultural machinery and equipment and transportation equipment grew during the three periods of the cycle: initially (2003-2004) driven by exports and subsequently

sharply in 2004, only to fall and rise again between 2007 and 2008, when it reached higher levels than in the past. 
(2006-2008 and 2008-2012) by an increase in domestic investment. These segments, as well as the segment that makes electrical generation and distribution equipment (demand for which grew only in the second and third periods of the cycle), were able to cover the increase in domestic demand. They were not greatly affected by imports, and once the maximum rate of installed capacity utilization had been achieved, they began to invest heavily to maintain their position as the main suppliers in the local market. The post-crisis slowdown did not fundamentally change this dynamic though it did moderate its intensity: the segments continued to grow on the back of the domestic market, albeit at a slower pace, while imported products gained a stronger foothold.

Conditions for the computer, electronics and optical equipment sector were much less favourable: unlike in the other sectors, the 2003-2004 expansion was propelled not by exports but rather by demand in the local market. However, in 2005, the supply for this demand started to come from imports, which had the effect of displacing national production and dampening investment.

Lastly, the industrial machinery and equipment segment faced the most difficult conditions. In response to robust domestic demand in the second period of the cycle, it ramped up growth but did not succeed in meeting all of the demand. In 2007, when it had put nearly all its production capacity to use, much of the demand in the local market was instead supplied by imports, which were benefitted by exchange rate appreciation. The situation deteriorated even further after the crisis, as sector investment fell and imports took a larger share of the local market. This called into question whether the sector had the capacity to meet a future increase in demand in the Brazilian economy, as discussed below.

\section{The machinery and equipment industry and industrial investments}

According to IBGE data, the sectors accounting for the highest levels of industrial investment were as follows: oil and gas, agro-industry, mining and, until 2008, paper and pulp and metallurgy. These sectors, which collectively represented $49.4 \%$ of investment in 2000-2002, came to account for $66.6 \%$ of investment in 2006-2008. In all, these industries more than doubled their level of investment in six years, to an average annual rate of $16 \%$, while the average annual investment rate of the other industries fell to $2.1 \%$. The concentration of investments continued after 2008 but only in the oil and gas, agro- industry and mining sectors, which accounted for $48.9 \%$ of investment in 2006-2008 and 56.0\% in 2010-2012.

An expansion in investment in some sectors after a long period of stagnation - accompanied by more limited growth, and even contraction, in others- led to some important differences within the industrial machinery and equipment sector that are worth noting and analysing. This subsection analyses the machinery and equipment industry supplying the sectors that posted the strongest investment growth, in order to assess the restrictions that the Brazilian economy may face if its growth continues to be driven by these sectors.

\section{(a) Machinery and equipment for petroleum exploration and production}

The sector that manufactures machinery and equipment for oil and gas exploration and production ${ }^{13}$ sells nearly all its products on the domestic market (see figure 8). Not coincidentally, this industry was virtually stalled until $2004,{ }^{14}$ despite the increase in the export ratio from $8.8 \%$ in 2000 to $18.0 \%$ in 2004 . However, starting in 2005, with domestic consumption growing, sector production for the national market began to rise, and as a result the export ratio fell from $18.0 \%$ in 2004 to $13.8 \%$ in 2012 (despite an increase in 2009). Of an increase of $\mathrm{R} \$ 5.01$ billion in the value of sector production between 2004 and 2012, only R \$ 605 million (12\%) corresponded to exports; the remaining $\mathrm{R} \$ 4.4$ billion ( $88 \%$ of production) corresponded to supply for the domestic market.

Although imports rose over the period of study, the import penetration ratio (in current prices) remained quite stable and relatively low (25.6\% in $2005,25.7 \%$ in 2008 and $24.9 \%$ in 2012). The conclusion, therefore, is that demand in the petroleum exploration and production sector was largely met by the national industry, though the increase in imported products was not negligible.

\footnotetext{
13 The IBGE classifies the sectors of Brazil's economy in accordance with the National Classification of Economic Activities (CNAE), of which there are two versions: CNAE 1.0 and CNAE 2.0. In addition to the products listed for activity 2851 (CNAE 2.0), which correspond to machinery and equipment for petroleum exploration and production, other products that are primarily used in this activity are included: 2813.2040, 2813.2050, 2813.2030, 2813.2060, 2813.2090, 2813.2100, 2813.2080, 2813.2110, 2813.2070, 2813.2130, 2813.2010 (CNAE 2.0). 14 Deflated using the Getulio Vargas Foundation's wholesale price index-global supply, sector production grew by $8.7 \%$ between 2000 and 2004 (2.1\% per annum).
} 
Brazil: production by destination and apparent consumption by origin in the machinery and equipment sector for petroleum exploration and production, 2000-2012 (Billions of reais)

Production by destination

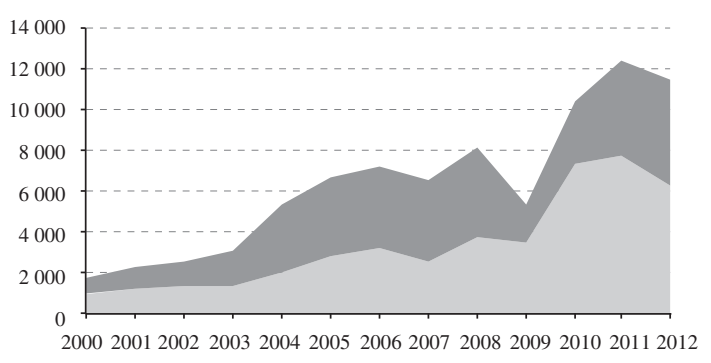

Exports Imports
Apparent consumption by origin

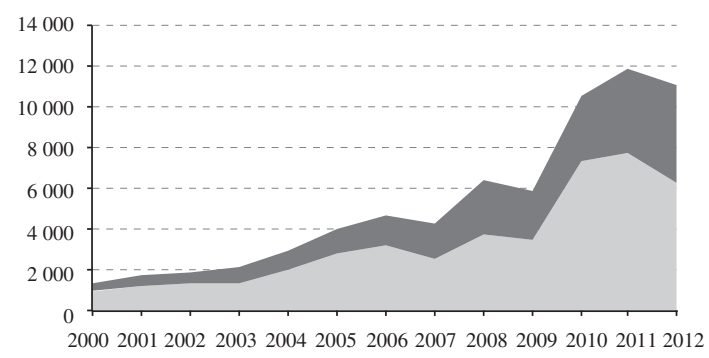

National production for the domestic market

Source: Prepared by the author, on the basis of data from the Brazilian Geographical and Statistical Institute (IBGE) and AliceWeb of the Ministry of Industry, Foreign Trade and Services.

It should be noted that despite stable import penetration ratios, the sector is characterized by a high level of intra-industry trade, which has become increasingly vertical in favour of the national industry. This means that the sector increasingly makes products with an array of technological values and that national products have more technology content than imports. ${ }^{15}$

15 Despite a slight contraction in recent years (from 0.56 in 2008 to 0.46 in 2012), the Grubel-Lloyd index for the sector is relatively high by virtue of Brazil's technology structure in the period under study. This indicates strong intra-industry trade. The ratio between the export unit value and the import unit value rose from 0.43 to 1.03 in 2008 , which means that the sector went from being vertical to horizontal. This ratio continued to evolve and stood at 1.58 in 2012, indicating that trade returned to being vertical but with national products characterized by a high level of technological sophistication (see annex A2).
The conclusion is that the national industry has been able to absorb much of the increase in demand, particularly for machinery that is more technologically sophisticated.

\section{(b) Machinery and equipment for mining and construction}

Unlike the machinery and equipment segment for petroleum exploration and production, exports are a major source of demand for machinery and equipment for mining and construction (see figure 9). Production in this segment climbed sharply in the first half of the 2000s (43.6\% in real terms between 2002 and 2004), primarily on external demand, and the export ratio rose from $42.6 \%$ in 2000 to $60.7 \%$ in 2004 .

FIGURE 9

Brazil: production by destination and apparent consumption by origin in the machinery and equipment sector for mining and construction, 2000-2012 (Billions of reais)

Production by destination

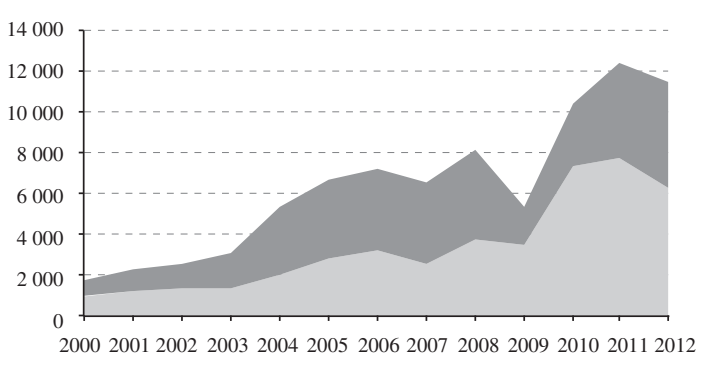

Exports Imports

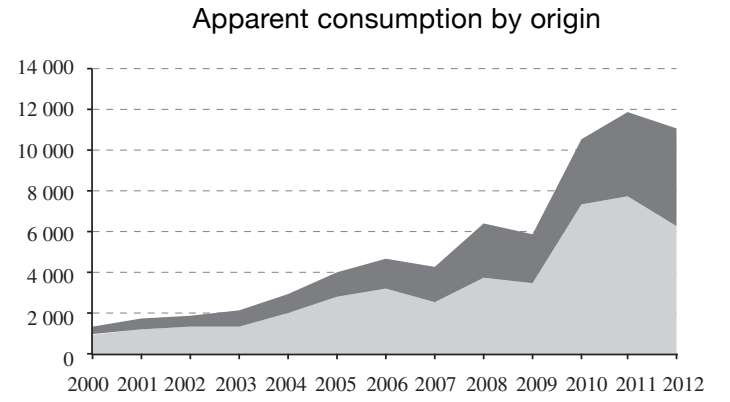

National production for the domestic market

Source: Prepared by the author, on the basis of data from the Brazilian Geographical and Statistical Institute (IBGE) and AliceWeb of the Ministry of Industry, Foreign Trade and Services. 
However, starting in 2004, the domestic market became a more significant source of demand for these goods, especially in the post-crisis period, causing the export ratio to fall to around $45 \%$ in 2012. Domestic consumption began to place upward pressure on demand, which grew at a faster pace than sector capacity to meet it. ${ }^{16}$ Essentially, due to its large export business, the sector was unable to meet domestic demand. The resulting dependence on imports led to substantial growth in that segment (at a rate of $435 \%$ between 2004 and 2008, as

16 This substitution of national products for imported products, in response to insufficient capacity in the national industry, is clearly indicated by the Grubel-Lloyd index for the sector, which increased from 0.20 in 2004 to 0.40 in 2008, where it remained, demonstrating an intensification of intra-industry trade. This intra-industry trade was primarily horizontal until 2008, as evidenced by the proximity to one of the ratio between the export unit value and the import unit value (with the ratio rising from 0.90 in 2004 to 1.12 in 2008), but then became vertical in favour of national supply (the export-import ratio increased to 1.43 in 2012) (see annex A2). measured in reais), and as a result the import penetration ratio, which had climbed from $30.2 \%$ in 2004 to $42.0 \%$ in 2008 , rose to $43.7 \%$ in 2012 .

Thus, the machinery and equipment sector for mining and construction had the technological potential to meet domestic demand, given the verticalization of trade in favour of national production, but could not absorb it entirely due to the disproportionate increase in demand between 2006 and 2011, which prompted a jump in imports.

(c) Machinery and equipment for the food, beverage and tobacco industries

National production of machinery and equipment for the food, beverage and tobacco industries is sold almost exclusively on the domestic market (see figure 10). This industry has a low export ratio (around 15\% through 2006 and falling to $6.8 \%$ in 2008), and unsurprisingly it posted significant growth in the second half of the 2000 s, buoyed by the local market.

FIGURE 10

Brazil: production by destination and apparent consumption by origin in the machinery and equipment sector for the food, beverage and tobacco industries, 2000-2012

(Billions of reais)

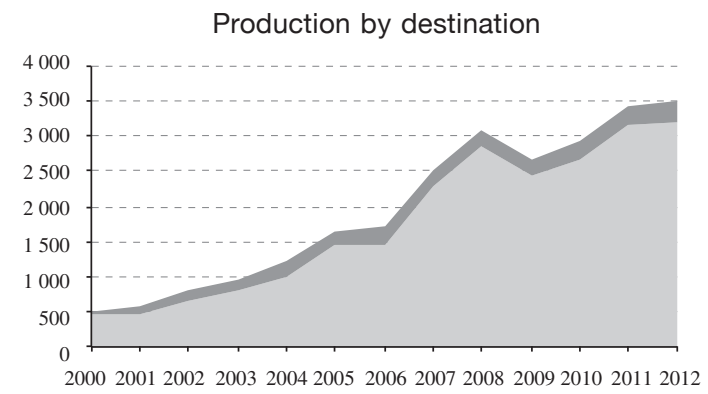

Exports Imports

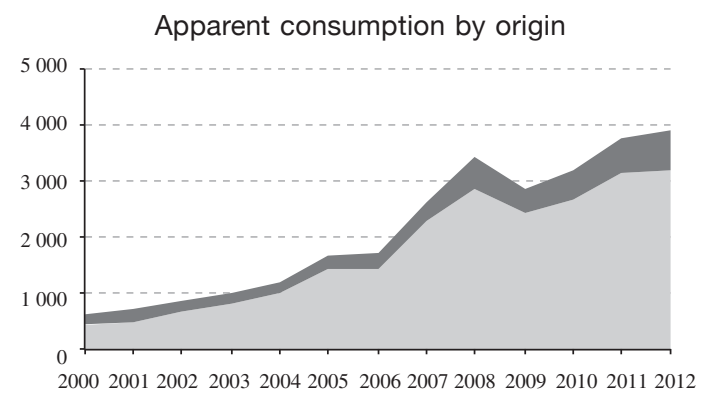

National production for the domestic market

Source: Prepared by the author, on the basis of data from the Brazilian Geographical and Statistical Institute (IBGE) and AliceWeb of the Ministry of Industry, Foreign Trade and Services.

Rising investment levels in the agro-industrial sectors led to an increase in sector production at a real rate of $19.3 \%$ in 2005 and $68.4 \%$ between 2006 and 2008. Demand growth prompted greater import activity, a segment that more than tripled in the period 20042008. ${ }^{17}$ However, due to appreciation in the Brazilian

17 The rate of increase, measured in reais, kilograms and dollars, was $197 \%, 213 \%$ and $374 \%$, respectively. real and proportional growth in apparent consumption, the expansion in imports did not translate into a larger import penetration ratio. After falling from $29.8 \%$ in 2000 to $15.5 \%$ in 2004, the ratio stabilized around $15 \%$ between 2004 and 2008.

Starting that year, the slower pace of investment had major repercussions for the machinery and equipment sector for the food industry, with production levels coming in lower in 2012 than in 2008, in real terms. A 
sharp increase in the import ratio notwithstanding, the production decline was not due to the competitiveness factor but rather to shrinking demand.

\section{(d) Machinery and equipment for the paper and pulp industries}

Despite a high export ratio, Brazil's machinery and equipment industry for paper and pulp production was virtually stalled during the first half of the 2000s, growing just $3.8 \%$ in real terms between 2002 and 2005. The only thing that prevented the industry from contracting during that period was export activity, which more than tripled (both in kilograms and dollars), ${ }^{18}$ underpinning the expansion in those years (see figure 11).

\footnotetext{
18 The result in reais was less significant, especially owing to the devaluation of the currency between 2002 and 2003 . However, between 2003 and 2005 , growth was $85 \%$.
}

Brazil: production by destination and apparent consumption by origin in the machinery and equipment sector for the paper and pulp industries, 2000-2012 (Millions of reais)

Production by destination

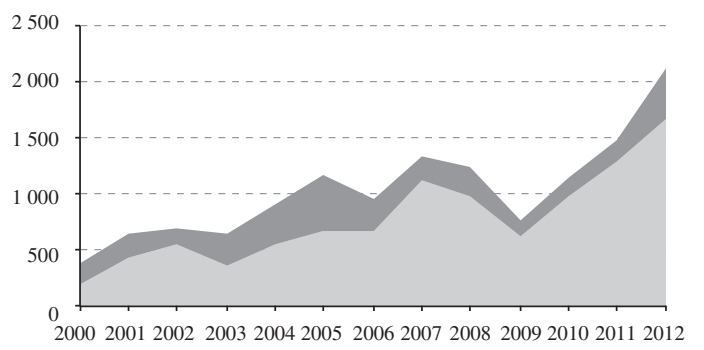

Exports

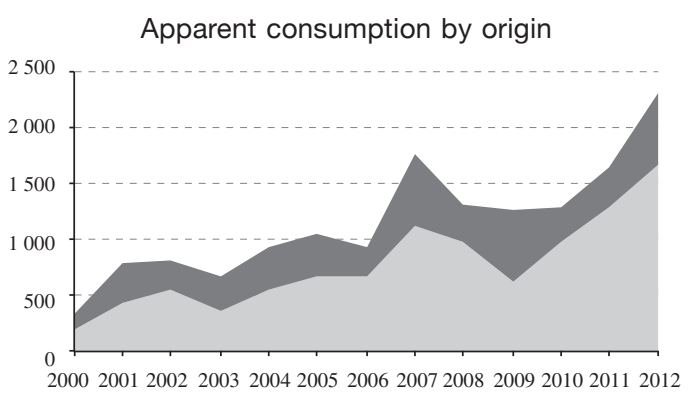

National production for the domestic market

Source: Prepared by the author, on the basis of data from the Brazilian Geographical and Statistical Institute (IBGE) and AliceWeb of the Ministry of Industry, Foreign Trade and Services.

Unlike the other segments analysed, the domestic market for machinery and equipment for the paper and pulp industry experienced its strongest growth in 2007, when apparent consumption (which was virtually stable) rose by $89.3 \%$. However, the increase in demand meant a significant loss of market share to imported products, as illustrated by an import penetration ratio that increased in current terms from $26.4 \%$ to $36.3 \%$.

The Grubel-Lloyd index for the sector indicated that trade was primarily inter-industrial in 2007 (0.29). ${ }^{19}$ And the domestic supply of machinery and equipment for the paper and pulp industries was unable to absorb the growth in domestic demand, owing to lack of production capacity as well as lack of diversification in the goods produced.

\footnotetext{
19 See annex A2.
}

(e) Machinery and equipment for metallurgy, excluding machine tools

Although exports were up at the start of the post-2003 expansion cycle, activity in the machinery and equipment sector for metallurgy remained nearly flat ${ }^{20}$ (see figure 12). However, sector production soared by $84.2 \%$ in real terms between 2005 and 2006, following a sharp increase in domestic demand. The jump in production, though, was not sufficient to meet domestic demand, especially because the goods made by Brazilian companies were technologically inferior to imports (with less unit value) and trade was primarily inter-industrial and vertical. ${ }^{21}$

\footnotetext{
${ }^{20}$ Between 2002 and 2004, sector production fell by $30.1 \%$ in real terms (value of production deflated using the Getulio Vargas Foundation's wholesale price index-global supply-machinery and equipment).

${ }^{21}$ In 2008, the Grubel-Lloyd index for the machinery and equipment sector for the metallurgy industry was 0.28 , and the ratio between the export unit value and the import unit value was 0.41 . This indicates primarily inter-industry and vertical trade (see annex A2).
} 
Brazil: production by destination and apparent consumption by origin in the machinery and equipment sector for metallurgy, excluding machine tools, 2000-2012 (Billions of reais)
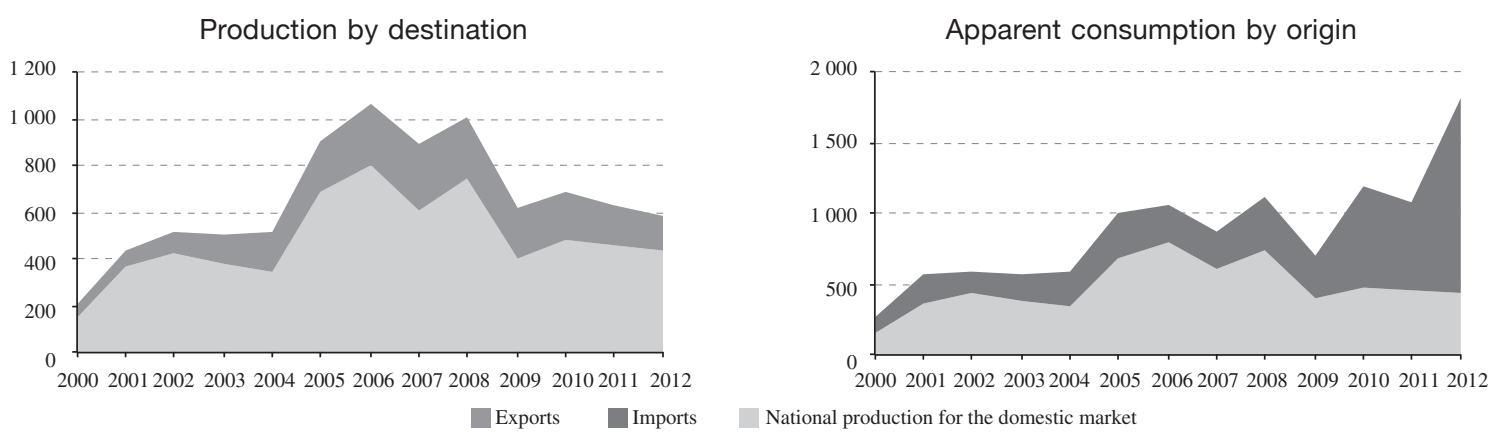

Source: Prepared by the author, on the basis of data from the Brazilian Geographical and Statistical Institute (IBGE) and AliceWeb of the Ministry of Industry, Foreign Trade and Services.

As a result, much of the increase in domestic demand for capital goods in the metallurgy industry, especially in 2008, was met with imports, inasmuch as local manufacturers had little import substitution capacity.

Starting in 2008, the technological inferiority of Brazilian products in this sector became even more evident, and flat investment in metallurgy further impaired the national machinery and equipment industry for metallurgy. The import penetration ratio stood at $76.1 \%$ in 2012, and the national industry, already stalled since 2006, began to shrink.

(f) Machinery and equipment for the textile, apparel and footwear industries

The machinery sector for the production of textiles, apparel and footwear was virtually stagnant for throughout the entire period of economic expansion (see figure 13). Although exports grew in relative terms through 2003, export activity began to drop off in 2004 and the domestic market was unable to sustain demand for Brazilian-made machinery. The expansion in the domestic market, though relatively small, was almost completely absorbed by imports. ${ }^{22}$ As a result, the import penetration ratio in the sector, which was already high, rose even higher, from $60.8 \%$ in 2005 to $72.4 \%$ in 2008 .

Against that backdrop, the national machinery and equipment industry for the production of textiles, apparel and footwear was unable to meet demand - actual or

22 Between 2005 and 2008 (the period of strongest investment growth in the sector), apparent consumption in the sector grew by $\mathrm{R} \$ 656$ million, of which $\mathrm{R} \$ 632.6$ million (96\%) was met with imports.

Brazil: production by destination and apparent consumption by origin in the machinery and equipment sector for the textile, apparel and footwear industries, 2000-2012 (Billions of reais)

Production by destination

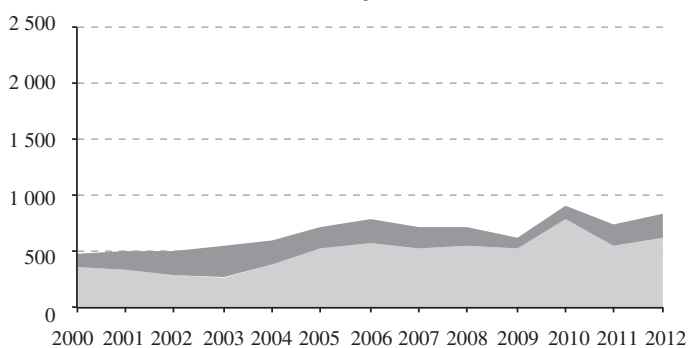

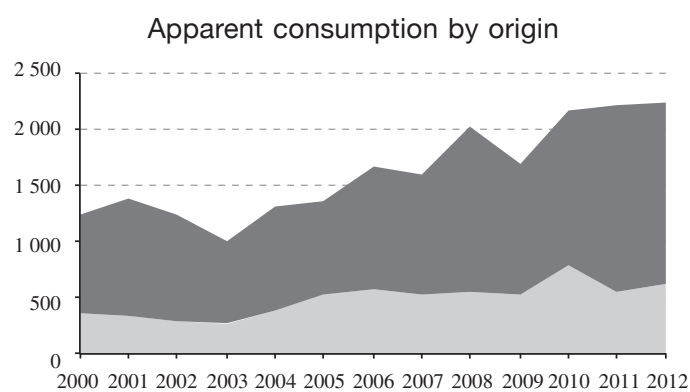

National production for the domestic market

Source: Prepared by the author, on the basis of data from the Brazilian Geographical and Statistical Institute (IBGE) and AliceWeb of the Ministry of Industry, Foreign Trade and Services. 
potential - in related sectors, pointing to near total dependence on machinery imports for expansion.

\section{(g) Summary of performance in the industrial machinery and equipment sector ${ }^{23}$}

Performance in the industrial machinery and equipment sector varies by segment and period of analysis. Three distinct periods can be identified: the first, from 2002 to 2004, was characterized by export-driven growth; the second, from 2005 to 2008, by a more lasting expansion that largely extended to all sectors; and the third, from 2008 to 2012 , by demand that continued to grow in some sectors and started to contract in others.

The main driver of demand in the first period was the foreign market. In those years, the machinery and equipment sector for mining and construction excelled, posting strong growth. Though less intense, the growth in the sector supplying the paper and pulp industry was notable too and almost entirely fuelled by the foreign market.

In contrast, demand in the second period was primarily driven by domestic investments in the industry. Although these investments stimulated production in sectors mainly oriented towards the local market, they also spurred imports. With the exception of the sector making machinery and equipment for the textile, apparel and footwear industries, in which domestic demand was covered almost entirely by imports due to lack of diversification in the national supply, all sectors took advantage of the demand in the second period to expand.

Lastly, the main driver of demand in the third period was the domestic market, but this was concentrated in the petroleum and gas and mining and construction sectors and so the benefits accrued above all to manufacturers

${ }^{23}$ See the summary of performance by period in the table in annex A3. of machinery and equipment for those industries. This led to stagnation in the other sectors, and in the less competitive cases, to expansion in the import sector, with imported products replacing national products.

The sectors that supply machinery and equipment for petroleum exploration and production and mining and construction grew in parallel with the imports that supplemented national supply, creating a horizontal intra-industry trade, i.e. the same types of products with similar technological content. Starting in 2008, trade in these sectors, which continued to expand, became vertical in favour of national production. In other words, national products came to have greater technological content than imported products.

Meanwhile, in the sectors that manufacture machinery and equipment for the paper and pulp, metallurgy and textiles, apparel and footwear industries, there was strong import growth. In the case of the sector supplying the paper and pulp industry, growth was evident above all in the supply of non-national products (inter-industry trade), due to lack of diversification in national supply. In the metallurgy and textile industries, the growth of imports replacing national products could be attributed to the fact that foreign products had significantly higher technological value than national products.

The sector supplying the food, beverages and tobacco industries was a unique case in the sense that there was little penetration by imported products, as well as low export ratios. Development in that sector was closely tied to the increase in demand from the second period (2006-2008), with lower demand in the post-crisis period directly affecting sector production. In short, this sector had sufficient potential to absorb domestic demand (both in technological and productive terms), but it is also very dependent on it.

\section{V}

\section{Conclusion: important considerations for an effective industrial policy for the capital goods sector}

The capital goods industry, when defined not by its productive aspects but rather its end purpose, is very diverse and includes a variety of sectors with distinct characteristics. In general, two groups can be distinguished based on their capacity to meet domestic demand: the sectors characterized by national production possessing the technological potential to absorb expansion in the domestic market, and the sectors with poorly diversified national production lacking the productive and technological capacity to compete with imported products.

As mentioned previously, the first group encompasses the sectors that manufacture transportation equipment, farm machinery and equipment, electrical generation and distribution equipment and machinery and equipment 
for petroleum exploration and production, for mining and construction, and, lastly, for the production of food, beverages and tobacco. These industries were largely able to meet domestic demand during the investment expansion cycle, and in the post-crisis period they experienced growth fuelled by domestic demand. The parallel expansion of imports, especially between 2005 and 2008, can be attributed not to the lack of technological diversification in the national productive apparatus but rather to lack of prior investment (which led to insufficient installed capacity) and macroeconomic imbalances, particularly exchange rate appreciation that favoured imports to the detriment of national production.

The second group consists of the sectors that manufacture machinery and equipment for the paper and pulp, metallurgy and textiles, apparel and footwear industries. In these branches of the capital goods industry, imports covered a disproportionate share of the expansion in domestic demand, owing especially to the lack of technological potential among national producers. For these industries, lack of national supply cannot be entirely explained by macroeconomic imbalances or lack of prior investment, which suggests that these segments would only be able to serve the internal market through policies targeted to and coordinated with the demand sectors for their products.

The computer, electronics and communications sector is an exceptional case in this second group. This sector's loss of competitiveness in the local market and the absorption of an increasing share of demand by imports should be understood as fairly unique inasmuch as this sector makes parts and components for other machinery and equipment industries. Thus, when import prices fell and these products displaced domestic supply, it was an opportunity for the other industries to expand.

In the case of the sectors of the capital goods industry that have the technological potential to cover expanded demand, industrial policy should focus on both coordination of investments (so demand for machinery does not overwhelm the national supply capacity) and scaling (to stimulate the creation of supply in the sectors of the machinery and equipment industry for which there will be demand in the future). ${ }^{24}$ To this end, the Brazilian government must position itself as an agent

\footnotetext{
${ }^{24}$ As explained by Rodrik (2004,p. 13), the coordination of investments and production decisions (by an organized private sector or at government initiative) is an important industrial policy mechanism, inasmuch as investments by company A often depend on the demand and investments of company B, and vice versa (simultaneous investing increases the profitability of all investments). This is not a new theory in the so-called "economics of development;" it was pioneered in the seminal article published by Rosenstein-Rodan (1943).
}

in the investment coordination and orientation process (either directly, as producer, or indirectly, as inducer), ${ }^{25}$ such that the sectors of the capital goods industry with technological potential can meet the demand that will be created. In the absence of coordination of supply and demand for investment goods, the sectors that currently have the potential to meet demand - such as the machinery and equipment sectors for the oil and gas, mining and food industries - will not be able to take advantage of the opportunities that emerge.

Furthermore, specifically in relation to these sectors with potential to meet domestic demand, industrial policy must be complemented by development-oriented macroeconomic policy that does not counteract industrial policy through abnormally high interest rates with respect to international patterns or a currency that appreciates cyclically in real terms. Such conditions are a perennial hindrance to the efficacy of financing instruments and make the business sector more risk averse, discouraging the creation of supply (Cano and Silva, 2010, p. 21). It is important to understand that these sectors can be competitive, even in foreign markets, if domestic demand is used to support their expansion. To ensure that opportunities for current growth are not wasted, efforts should be made to consolidate an "authentic competitiveness," supporting the absorption of domestic demand and promoting export activity, through tariff neutrality and exchange rates that are slightly depreciated in real terms, taking care that they remain stable over the long run (ECLAC, 2000, p. 906).

As noted by Coutinho (2011, pp. 33-34), lead or "anchor" companies and programmes have an important role to play in mobilizing funding for research, which translates into technology development for the country. According to Coutinho, the examples set by Petrobras (with major technological advances in deepwater exploration) and some agribusiness firms (which, with the support of the Brazilian Agricultural Research Enterprise (EMBRAPA), have enabled technological development at a number of Brazilian companies) demonstrate that there is generally a powerful company taking the lead in sectors where major advances are being made.

As mentioned, the opportunities available at present in the Brazilian economy require an effective policy for

\footnotetext{
${ }^{25}$ Responsibility for coordinating investments should not necessarily fall to the government. According to Almeida (2009), the formation of national groups promotes the formation of a chain of national suppliers, through the coordination of investments and an industrial policy. Moreover, as noted by Laplane (2004), orientation and coordination also require a foreign policy focused on the regional integration strategy of the supply chains, given the importance of demand in the neighbouring countries.
} 
the capital goods sector. The recent expansion in the domestic market (especially, its impact on investment), the enhanced capacity of the government to use its procurement and financing power (with respect to the fiscal crisis that began in the 1980s), the direction of foreign capital flows (which can spur direct investments with technology transfer), higher commodity prices (which would avoid external constraints, at least in the short run) and the presence of firms with technological potential are some of the factors that should be considered in the consolidation of a policy to promote sector competitiveness.
If the country fails to take advantage of the expansion in the domestic market as a strategic variable for shoring up a national industry vulnerable to swings in demand — as is the case with the capital goods industry — and also fails to consider the systemic factors cited in this paper (which would promote an orderly and selective process), the lack of supply capacity in the capital goods sector could impose future constraints on the development of the economy, in terms of both the balance of payments and technological dependence. If that were to happen, economic growth could again be hindered by a reversal in external conditions.

\section{Bibliography}

Alem, A.C. and R.M. Pessoa (2005), "O setor de bens de capital e o desenvolvimento econômico: quais são os desafios?”, bndes Setorial, No. 22, Rio de Janeiro, Brazilian Development Bank.

Almeida, M. (2009), "Desafios da real política industrial brasileira do século XxI", Texto para Discussão, No. 1452, Institute of Applied Economic Research (IPEA), December.

Amsden, A.H. (2001), Asia's Next Giant: South Korea and the Late Industrialization, New York, Oxford University Press.

Baltar, C.T. (2007), "Padrão do comércio brasileiro no período 2003-2005: um estudo do conteúdo dos fluxos de importação e exportação", Campinas, Institute of Economics/State University at Campinas.

Bielschowsky, R. (1999), "Investimentos na indústria brasileira depois da abertura e do real: mini-ciclo de modernizações. 1995-97”, Reformas Económicas series, No. 44 (LC/L.1289), Santiago, Economic Commission for Latin America and the Caribbean (ECLAC)

Cano, W. and A.L.G. Silva (2010), "Política industrial no governo Lula", Texto para Discussão, No. 181, Campinas, Institute of Economics/State University at Campinas.

Coutinho, L. (2011), "O Brasil do século XXI: desafios do futuro", $O$ Brasil do século xxi, A. Delfim Netto (coord.), São Paulo, Saraiva.

ECLAC (Economic Commission for Latin America and the Caribbean) (2000), "Estudo econômico da América Latina, 1949", Cinqüenta anos de pensamento na cepal, R. Bielschowsky (org.), vol. 1, Rio de Janeiro, Editora Record.

(2000), "Política de ajuste e renegociação da dívida externa na América Latina", Cinqüenta anos de pensamento na cepal, R. Bielschowsky (org.), vol. 2, Rio de Janeiro, Editora Record.

Erber, P.S. (coord.) (1974), "Absorção e criação de tecnologia na indústria de bens de capital", finep Séries Pesquisas, No. 2, Rio de Janeiro, Arte Moderna.

Feltrin, L. (2005), "Mudanças estruturais na inserção brasileira no comércio internacional de bens de capital: 1991-2000", Perspectiva Econômica, vol. 1, No. 2.
Gouvea, R.R. and G.T. Lima (2013), "Balance-of-paymentsconstrained growth in a multisectoral framework: a panel data investigation", Journal of Economic Studies, vol. 40, No. 2, Emerald Group Publishing.

Laplane, M. (2004), "A política industrial em perspectiva", Econômica, vol. 5, No. 2, Rio de Janeiro.

Lundvall, B.-A. (1988), "Innovation as an interactive process: from user-producer interaction to the national system of innovation", Technical Change and Economic Theory, G. Dosi and others (ed.), London, Pinter Publishers.

Nassif, A. (2008), "The structure and competitiveness of the Brazilian capital goods industry", cepal Review, No. 96 (LC/G.2396-P), Santiago, Economic Commission for Latin America and the Caribbean (ECLAC).

Resende, M.F.C. and P. Anderson (1999), "Mudanças estruturais na indústria brasileira de bens de capital", Texto para Discussão, No. 658, Brasilia, Institute of Applied Economic Research (IPEA) [online] http://www.ipea.gov.br/agencia/images/stories/ PDFs/TDs/td_0658.pdf.

Rodrik, D. (2004), "Industrial policy for the twenty-first century", Faculty Research Working Paper Series, No. RWP04-047, Harvard University [online] https://research.hks.harvard.edu/ publications/getFile. aspx? Id=146.

Rosenstein-Rodan, P.N. (1943), "Problems of industrialisation of Eastern and South-Eastern Europe", The Economic Journal, vol. 53 , No. 2 .

Serrano, F. and R. Summa (2011), "Política macroeconômica, crescimento e distribuição de renda na economia brasileira dos anos 2000", Observatório da Economia Global, No. 6 , Campinas, State University at Campinas.

Vermulm, R. and F. Erber (2002), Estudo da competitividade das cadeias integradas no Brasil: impactos das zonas de livre comércio. Cadeia: bens de capital - Nota Técnica Final, Campinas, Institute of Economics/State University at Campinas. 
ANNEXES

ANNEX A1

Brazil: segmentation of the capital goods industry ${ }^{a}$

\begin{tabular}{|c|c|c|}
\hline Groups and subgroups & CNAE $2.0^{\mathrm{b}}$ & CNAE $1.0^{b}$ \\
\hline \multicolumn{3}{|c|}{ Computer, electronics, instruments and optical equipment } \\
\hline Computer and peripheral equipment & 262 & 302 \\
\hline Communication equipment & 263 & 322 \\
\hline Metering, testing and control devices and equipment & 2651 & 332 and 333 \\
\hline Electromedical and electrotherapy devices and radiation equipment & 266 & 331 \\
\hline Optical, photographic and cinematographic instruments and equipment & 267 & 334 \\
\hline
\end{tabular}

Electrical generation, distribution and control equipment

Electric generators, transformers and motors

Electrical distribution and control devices and equipment

271

2731

311

3121

Tractors, machinery and equipment for agro-industry

\begin{tabular}{|c|c|c|}
\hline Tractors, machinery and equipment for agro-industry & 283 & 293 \\
\hline \multicolumn{3}{|c|}{ Industrial machinery and equipment } \\
\hline Motors, pumps, compressors and transmission equipment & 281 & 291 \\
\hline General use machinery and equipment & 282 & 292 and 301 \\
\hline Machine tools & 284 & 294 \\
\hline Machinery and equipment for petroleum exploration and production & 2851 & 2951 \\
\hline Tractors, except farm & 2853 & 2953 \\
\hline Machinery and equipment for mining and construction & 2852 and 2854 & 2952 and 2954 \\
\hline Machinery for the metallurgy industry, except machine tools & 2861 & 2961 \\
\hline Machinery and equipment for the food, beverage and tobacco industries & 2862 & 2962 \\
\hline Machinery and equipment for the textile industry & 2863 & 2963 \\
\hline Machinery and equipment for the apparel, leather and footwear industries & 2864 & 2964 \\
\hline Machinery and equipment for the pulp, paper, cardboard and packaging industries & 2865 & 2965 \\
\hline Machinery and equipment for specific industrial uses not specified above & 2866 and 2869 & 2969 \\
\hline \multicolumn{3}{|l|}{ Transportation equipment } \\
\hline Trucks, buses, cabins, trailers and hitches & 292 and 293 & 342 and 343 \\
\hline Boats and floating structures & 3011 & 3511 \\
\hline Trains, railroad cars and other rolling stock & 3031 & 3521 \\
\hline Airplanes & 304 & 3531 \\
\hline
\end{tabular}

Source: Prepared by the author, on the basis of data from the National Classification Commission (CONCLA)-Brazilian Geographical and Statistical Institute (IBGE).

a Versions 1.0 and 2.0 of the National Classification of Economic Activities (CNAE) were harmonized based on data from the National Classification Commission (CONCLA) of the Brazilian Geographical and Statistical Institute (IBGE) for the purpose of extending the comparison to the entire period of analysis. Harmonization of the two versions is necessary inasmuch as data are taken from the Annual Survey of Industry-Enterprise and the Annual Survey of Industry-Product, both prepared by IBGE, which were published at different times: the first between 1996 and 2007, in the framework of CNAE 1.0, and the second between 2007 and 2012, in the framework of CNAE 2.0. For the analysis, data on foreign trade were also collected from the Centre for Foreign Trade Studies Foundation (FUNCEX) and AliceWeb of the Ministry of Industry, Foreign Trade and Services (MDIC). In this case, the harmonization was based on the MERCosur Common Nomenclature (MCN), which is the classification used by the MDIC for trade data.

b Versions 1.0 and 2.0 of the CNAE do not necessarily yield the same results, as some of the products in one classification are not included in the harmonized group of the other classification. 
Brazil: other indicators of trade in industrial machinery and equipment sectors

A. Ratio between export and import unit values

\begin{tabular}{lcccccccccc}
\hline & 2000 & 2001 & 2002 & 2003 & 2004 & 2005 & 2006 & 2007 & 2008 & 2009 \\
\hline Petroleum exploration and production & 0.54 & 0.52 & 0.58 & 0.60 & 0.43 & 0.50 & 0.60 & 0.64 & 1.03 & 1.34 \\
Mining and construction & 0.79 & 0.96 & 0.97 & 0.77 & 0.90 & 0.90 & 0.84 & 0.99 & 1.12 & 1.00 \\
Metallurgy, excluding machine tools & 0.21 & 0.18 & 0.25 & 0.28 & 0.36 & 0.29 & 0.41 & 0.44 & 0.41 & 0.44 \\
Food, beverages and tobacco & 0.29 & 0.19 & 0.27 & 0.30 & 0.24 & 0.35 & 0.32 & 0.43 & 0.29 & 0.31 \\
Textiles, apparel and footwear & 0.60 & 0.58 & 0.57 & 0.62 & 0.62 & 0.72 & 0.75 & 0.81 & 0.96 & 0.83 \\
Paper and pulp & 0.69 & 0.78 & 0.60 & 0.63 & 0.54 & 0.60 & 0.82 & 0.81 & 0.91 & 0.64 \\
\hline
\end{tabular}

Source: Prepared by the author, on the basis of data from AliceWeb of the Ministry of Industry, Foreign Trade and Services.

B. Grubel-Lloyd index

\begin{tabular}{lccccccccccc}
\hline & 2000 & 2001 & 2002 & 2003 & 2004 & 2005 & 2006 & 2007 & 2008 & 2009 & 0.5 \\
Petroleum exploration and production & 0.37 & 0.36 & 0.52 & 0.54 & 0.55 & 0.62 & 0.65 & 0.57 & 0.56 & 0.42 \\
Mining and construction & 0.36 & 0.31 & 0.33 & 0.28 & 0.20 & 0.25 & 0.29 & 0.38 & 0.39 & 0.40 \\
Metallurgy, excluding machine tools & 0.39 & 0.21 & 0.32 & 0.32 & 0.38 & 0.35 & 0.35 & 0.32 & 0.28 & 0.28 & 0.35 \\
Food, beverages and tobacco & 0.37 & 0.46 & 0.56 & 0.56 & 0.52 & 0.49 & 0.40 & 0.55 & 0.45 & 0.43 \\
Textiles, apparel and footwear & 0.09 & 0.10 & 0.13 & 0.15 & 0.16 & 0.21 & 0.15 & 0.16 & 0.18 & 0.16 \\
Paper and pulp & 0.31 & 0.25 & 0.38 & 0.39 & 0.51 & 0.37 & 0.48 & 0.29 & 0.51 & 0.26 \\
\hline
\end{tabular}

Source: Prepared by the author, on the basis of data from AliceWeb of the Ministry of Industry, Foreign Trade and Services.

ANNEX A3

Brazil: summary of performance in the industrial machinery and equipment sector

\begin{tabular}{|c|c|c|c|}
\hline Segment & $1^{\text {st }}$ period $(2002-2004)$ & $2^{\text {nd }}$ period $(2005-2008)$ & $3^{\text {rd }}$ period $(2008-2012)$ \\
\hline $\begin{array}{l}\text { Petroleum } \\
\text { exploration } \\
\text { and production }\end{array}$ & $\begin{array}{l}\text { Stagnant domestic market } \\
\text { and low export ratio }\end{array}$ & $\begin{array}{l}\text { Growth based on the domestic market, but } \\
\text { in parallel with imports (horizontal intra- } \\
\text { industry trade) }\end{array}$ & $\begin{array}{l}\text { Growth based on the domestic market, } \\
\text { with intensification of technological content }\end{array}$ \\
\hline $\begin{array}{l}\text { Mining and } \\
\text { construction }\end{array}$ & Export-driven growth & $\begin{array}{l}\text { Growth based on exports and the domestic } \\
\text { market, but with a sharp increase in imports } \\
\text { (horizontal intra-industry trade) }\end{array}$ & $\begin{array}{l}\text { Growth based on exports and the domestic } \\
\text { market, with intensification of } \\
\text { technological content }\end{array}$ \\
\hline $\begin{array}{l}\text { Food, beverages } \\
\text { and tobacco }\end{array}$ & $\begin{array}{l}\text { Stagnant domestic market } \\
\text { and low export ratio }\end{array}$ & $\begin{array}{l}\text { Growth based on the domestic market, but } \\
\text { in parallel with imports (horizontal intra- } \\
\text { industry trade) }\end{array}$ & $\begin{array}{l}\text { Stagnation due to lower investments } \\
\text { and difficult access to external market }\end{array}$ \\
\hline Paper and pulp & $\begin{array}{l}\text { Low growth despite high } \\
\text { export ratio }\end{array}$ & $\begin{array}{l}\text { Growth based on the domestic market in } \\
\text { 2007, but with a sharp increase in imports } \\
\text { (inter-industry trade: lack of diversification } \\
\text { in the national supply) }\end{array}$ & $\begin{array}{l}\text { Stagnation due to lower investments } \\
\text { and lack of diversification, which favoured } \\
\text { the penetration of imports }\end{array}$ \\
\hline $\begin{array}{l}\text { Textiles, apparel } \\
\text { and footwear }\end{array}$ & $\begin{array}{l}\text { Stagnation and an increase } \\
\text { in the export ratio }\end{array}$ & $\begin{array}{l}\text { Low growth, with the domestic market } \\
\text { absorbed almost completely by imports } \\
\text { (inter-industry trade: lack of diversification } \\
\text { in the national supply) }\end{array}$ & $\begin{array}{l}\text { Contraction due to lower investments } \\
\text { and an increase in imports with greater } \\
\text { technological content }\end{array}$ \\
\hline
\end{tabular}

Source: Prepared by the author. 